This is an Accepted Manuscript of a chapter published by Taylor \& Francis Group in Denisoff D \& Schaffer T (eds.) The Routledge Companion to Victorian Literature. Routledge Literature Companions. Abingdon: Routledge on 4 Nov 2019, available online:

https://www.routledge.com/The-Routledge-Companion-to-Victorian-Literature-1stEdition/Denisoff-Schaffer/p/book/9781138579866

\title{
New Religions and Esotericism
}

For many years, the story of religion in nineteenth-century Britain was narrated primarily, even sometimes exclusively, in relation to doubt, decline, and disenchantment. Drawing upon an evocative literary terrain composed of Matthew Arnold's receding Sea of Faith and John Ruskin's dreadful Hammers (Arnold 21; Ruskin 115)., scholars painted the period as one in which secularization was inevitable, undeterred, and productive of crisis. Indeed, writing in 1977, Robert Lee Wolff suggests that religious doubt was so inescapable during the years of Victoria's reign that practically every citizen experienced their own bespoke variety of it. "Victorians," he writes, "were troubled not only about what to believe and how to practice their religion, but also about whether to believe at all, and how continued belief might be possible [. . . ] There seem at time to have been as many varieties of doubt as there were human beings in Victorian England" (2). While staking this claim in an introduction to a reprint series of one hundred and twenty-one Victorian novels specifically selected to reflect the faith and doubt paradigm, Wolff makes no allowance for a possible incongruence between his pointed thematic focus and the experience of the general populace at large. Surveying a demographic which grew in size from some thirteen to thirty-two million between 1837 and 1901, he confidently assigns to it a single spiritual keynote: doubt.

The scholarly landscape has changed significantly since the time of Wolff's pronouncement. The pioneering work of Alex Owen, Timothy Larsen, Joshua King and others has shown us that the rumours of religion's death, or even anxiogenic retreat, in 
nineteenth-century Britain have been much exaggerated. ${ }^{1}$ Far from simply waning, religion transformed and adapted in the wake of secularization; furthermore, the more liberal social and political conditions which this process ushered worked to foster rather than suppress the growth of new religious formations and spiritual identities. Consider for example the case of the Anglican Church, an institution which held a stranglehold on state power in England at the start of the nineteenth century; only those (men) who had received its communion and accepted its thirty-nine articles were eligible to serve as Members of Parliament or to take degrees at Oxford or Cambridge. In the decades which followed, such restrictions and sanctions against those outside the Anglican fold would gradually drop-1828 saw the repeal of the Test Act, which had mandated Church of England membership of all government officials; in 1833 the franchise was extended to Jewish men who met the property requirement; and male Dissenters and Jews were admitted to degree courses at Oxford and Cambridge in 1854 and 1856 respectively (Melnyk 43). By the mid-century, Catholic, Dissenting, and Jewish men no longer had fewer legal rights than their Anglican counterparts, and, while still subject to religious bigotry, were able to claim more space in the public sphere. This loosening of Church authority helped to produce a more liberal faith environment in which qualms or doubts about Christian doctrine, many of which long predated the Victorian era, were able to be expressed more freely. "[W]hat had changed from the eighteenth century, " writes Larsen, "was not so much that some people now doubted, as that more of those who did now insisted on being open and honest about it" (11). New challenges to scriptural authority emanating from the domain of science in this periodmost notably Darwinian natural selection and Lyell's geological gradualism- may have

See Owen 1989 and 2004; Knight and Mason 2006; Larsen 2006; Melnyk 2008; King 2015. 
intensified these doubts for some, but they did not exclusively originate them; furthermore, as the success of Robert Chamber's (1802-1871) Vestiges of the Natural History of Creation (1844) demonstrates, believers were perfectly capable of reconciling such paradigm shifts with continued faith in a loving God. This new flexibility and diversification of religion compels us to exercise caution as we consider the well-documented decline of Church attendance in this period (Melnyk 155). Rather than signifying a straightforward rejection of spiritual identity per se, this drop off might be equally representative of a growing dissatisfaction with traditional forms of Christian observance, authority, and eschatology.

Nowhere is this dissatisfaction more apparent than in the explosion of new religions and esoteric movements which alternately originated or took root in Britain during the nineteenth century. Some of these, including Mormonism and Christian Science, clearly situated themselves within the Christian tradition, albeit offering new scriptural interpretations and/or gospels; others, such as the Modern Spiritualism, the Theosophical Society, and the Hermetic Order of the Golden Dawn, had no explicit or exclusive connection to Christianity at all, or were in some cases directly critical of its teachings. Before discussing such currents in further detail, we must scrutinize our focal descriptors, some of which are not only anachronistic to the era under discussion, but would have been vehemently rejected by those believers to whom they are latterly applied. What is esotericism, and what is a new religion; and are the two interchangeable? The quick answer is 'not necessarily,' although some movements such as Theosophy can and have been described as both. ${ }^{2}$ Each definitional category has been subject to an extensive and (2006), where it is assessed as an esoteric current, and a chapter in The Cambridge Companion to New Religious Movements (2014), where it features as a new religion. Both submissions are written by Theosophical scholar James Santucci: see Santucci 2006 and 2014. 
ongoing critical interrogation that it will be impossible to fully reproduce here; researchers seeking an introduction to such debates should consult Lewis (2003), Stuckrad (2005), Bergunder (2010), and Hanegraaff (2012).

Etymologically, "esotericism" first appeared as a substantive noun in the early nineteenth century, featuring initially in French in Jacques Matter's Histoire Critique du Gnosticisme et du Son Influence (1828) and then in English later in the century. ${ }^{3}$ It gained popular currency through association with the high-profile magical practitioners Éliphas Lévi (1810-75) and Helena Petrovna Blavatsky (1831-91), who used the term to describe an allegedly ancient set of secret spiritual truths long suppressed by the Church but preserved through the ages by a hidden band of initiates. Now ready for dissemination to carefully trained seekers, this wisdom promised to open a window into the concealed world of spirit and restore to their rightful place the occult sciences discarded by enlightenment modernity - alchemy, scrying, astral projection, clairvoyance, astrology, and spirit communion, to name just a few. Understood in this way, esotericism promoted individualism through its emphasis on the importance of spiritual self-development; seekers were encouraged to forge a direct, albeit carefully prepared, relationship with the supernal world. Like many traditional Christian believers in this period, Victorian students of esotericism also rejected what they viewed as the cruel and irrational doctrine of damnation, preferring instead to envision a future in which the individual human monad continue to grow and improve after the death of its physical body. Victorian esotericists routinely articulated this narrative of progress through what Olav Hammer terms a discourse of "scientism" (203), one in which the rhetoric, specialized vocabulary, and English to J.E. Worcester's 1846 Universal and Critical Dictionary of the English Language ("Esotericism"). 
theories_if never the methods_of scientific naturalism were invoked to legitimize spiritual claims. Thus, for example, H.P. Blavatsky could claim in her esoteric magnum opus /sis Unveiled (1877) that "the discoveries of modern science do not disagree with the ancient traditions" of ancient Egyptian medicine (Blavatsky 1877), without subsequently feeling any compunction to test this alignment under laboratory conditions or to publish the results of her occult researches in scientific journals where they might be reproduced or discredited.

Such techniques and positions contributed vitally to what is now known as the nineteenth-century "occult revival," namely the surge of public interest in supernatural phenomena and belief fostered, if not solely initiated, by the advent of Modern Spiritualism in mid-century New York State. ${ }^{4}$ While often linked, and frequently sharing the same constituents, esotericism and Modern Spiritualism are however by no means identical. 5 The rhetoric of secrecy that, as Kocku Von Stuckrad has shown, has become so important to esoteric groups had little to no value within the decidedly more exoteric milieu of Victorian Spiritualism. Notoriously heterodox, spiritualists shared no common belief except for their insistence that it was possible to communicate with the dead (Oppenheim 95). Far from concealing the results of their séances, or sharing them only via initiation, they sought to publicize them as widely as possible. Anyone with a table and planchette, they argued, could and should attempt to contact their beloved dead; those in esoteric movements, by contrast, tended to emphasize caution, preparation, and selectivity as prerequisite to any excursion into the realm of spirit, even if their actual membership criteria were quite broad.

\footnotetext{
$4 \quad$ For more on the complex origins of the occult revival in Britain, see Godwin 1994 and Sommers 2018. 5 Best known for her co-founding of the Theosophical Society, H.P. Blavatsky also championed and practiced spiritualist mediumship in the early seventies; renowned as a spiritualist medium and propagandist, Emma Hardinge Britten was also an early member of the Theosophical Society, a putative affiliate of the Hermetic Brotherhood of Luxor, and an alleged participant in the Orphic Circle. See Godwin 1994 for more on these women's contributions to occultism and spiritualism.
} 
Applicable to all faith groups at some (early) point in their institutional history, the term "new religion" is today most frequently applied to religions of post-Enlightenment origin, and in particular to those produced as part of "wave of non-traditional religiosity" elicited by the West's mid-twentieth-century counterculture (Lewis and Tøllefson 2)— Scientology, Wicca, the International Society of Hare Krishna, the Rajneesh Movement, Heaven's Gate, and Raëlism, to name just a few. Such emergent spiritual collectivities have often been viewed with suspicion by the established religious mainstream due to their participation in unorthodox, controversial, or sometimes dangerous activities; indeed, as Olav Hammer and Mikael Rothstein point out, their legitimation as subjects for serious academic inquiry owes much to the anti-cult controversies of the 1970 (2). New religions can be esoteric in teaching and structure, as Henrik Bogdan reminds us, but they need not necessarily be so; only those which prioritize "the discourse on secrecy and unveiling," he suggests, belong in this category (Bogdan 457). Nonetheless, many of today's new religions are indebted to concepts first popularized by nineteenth-century esoteric movements, such as the figures of the Theosophical Masters who have since become central to the "I AM" group and the Church Universal and Triumphant. While Victorian esoteric groups were often described by their contemporary observers as "new religions,"6 and are sometimes still classified as such, 7 it is worth remembering that many of their members would have aggressively rejected one or both parts of this designation. Theosophists, for example, claimed an ancient provenance for the beliefs, insisting that their teachings predated those of all the established world religions by some tens of

$6 \quad$ Consider for example the reviews of Alfred Percy Sinnett's Theosophical novel Karma (1885), which consistently referred to occultism and Theosophy as "new religions." See "Recent Novels" (13) and "Opinions of the Press" (1-2).

$7 \quad$ See Santucci (2014) and Bogdan. 
thousands of years. ${ }^{8}$ To a movement which derived authority from the supposed antiquity of its tenets and supernatural intermediaries, any charge of novelty would have been greeted as an insult. Similarly, Blavatsky refused the badge of "religion" for her movement, associating this term with the narrow sectarianism, materialism, and hypocrisy which Theosophists routinely diagnosed in contemporary Christianity. ${ }^{9}$ Elsewhere, it was not so much the negative connotations of religion which bothered Theosophists, as the indefinite article which typically preceded it; in 1888, the London-based Theosophical journal Lucifer claimed, "Theosophy is not a Religion [. . .] but RELIGION itself, the one bond of unity, which is so universal and all-embracing that no man [. . . can be outside its light." ("Is Theosophy a Religion?" 179-80). Ironically, of course, many of these exact arguments, in particular the argumentum ad anitquitatem, are now recognized as definitive characteristics of new religions (Hammer and Rothstein 8); one could say, then, that Theosophy never seemed more like a new religion than when it was insisting on its great age. As applicable as the "new religion" designation might today seem to such movements, however, we must nonetheless remain sensitive to the complexities and problems of retrospective classification, and aim to avoid conceptualizing them in ways that would have been wholly unrecognizable, or unwelcome, to their historical participants.

The statistical impact of esoteric and new religious movements on the Victorian religious landscape is difficult to assess. The 1851 Census of Religion, which enumerated believers on the basis of attendance at religious services, predated many of the era's most

$8 \quad$ In the introduction to Volume I of Isis Unveiled (1877), for example, Blavatsky argues that the Theosophical theory of emanationism is "founded upon seventy thousand years of experience" and "has been entertained by hermetic philosophers of all periods" (Blavatsky).

9 See "Lucifer to the Archbishop of Canterbury" (1887), "Sunday Devotion to Pleasure" (1888), and Adversa (1888). 
influential new religious movements, such as Christian Science; ${ }^{10}$ furthermore, it did not include participation in spiritualist séances or magical initiation ceremonies within its return categories. R.A. Gilbert, in an admirably painstaking attempt to reconstruct this lost history, notes that the two censuses of British spiritualist societies conducted in 1868 and 1880 respectively never recorded more than 3,200 members in total; the membership figures for late-century esoteric institutions like the Theosophical Society and the Hermetic Order of the Golden Dawn are even lower (Gilbert 17; 20-21). If we confine our analyses of such movements to their card-carrying, paid-up members alone, their influence will seem to have been so small as to be almost negligible- such, indeed, is the very conclusion that Gilbert reaches, causing him to declare that "there was no occult revival" (231) in nineteenth-century Britain. Such a verdict, however, seems premature. Theosophy and Spiritualism were heterodox spiritual currents which did not require official membership, specific observance rituals, or doctrinal conformity from the seekers in their folds; while valuable historical documents, the subscription lists of their societies will never tell us how many people conducted séances in their own homes or privately subscribed to the beliefs in clairvoyance or metempsychosis popularized by esoteric writers.

If we turn to the realm of literature, however, the impact of esotericism and new religions - and indeed of esoteric new religions-on Victorian culture is both easier to calculate and much more significant. In the latter half of the century when the occult revival was taking root in Europe, the British fiction market was saturated with esotericallyattuned themed plots and motifs; furthermore, when the triple-decker publishing format finally collapsed at the fin de siècle, it was occult novels such as Marie Corelli's (1855-1924) A

\footnotetext{
10 Indeed, of the thirty-five religions listed in the report, only two-the Latter-Day Saints of Jesus Christ, and the Plymouth Brethren-might have been contemporarily described as "new religions." See Census of Great Britain 1851.
} 
Romance of Two Worlds (1886) and The Sorrows of Satan (1895) which dominated the bestseller lists. The era's occultural turn arguably had its most profound influence not on the religious but on the literary marketplace. We can observe this effect with particular clarity in the fictional reception and creative repurposing of one of the most controversial esoteric beliefs to be culturally mainstreamed during Victoria's reign: namely, reincarnation.

\section{Reincarnation in Victorian Britain}

Reincarnation belief, as Olav Hammer points out, had virtually no significant presence in the West until the latter part of the nineteenth century (Hammer 455); the fact that the concept is so well known today owes much to the proselytizing efforts of a single late Victorian esoteric movement: Theosophy. So central was Theosophy to the popularization of reincarnation, writes Helmut Zander, that, in this respect, its "significance [. . . ] cannot be overestimated" (985-6). Not initially a central tenet of the Society's philosophy, it became so several years after two of the organization's key founders, H.P. Blavatsky and Henry Steel Olcott (1832-1907), moved to India in 1879 to seek inspiration and new converts. ${ }^{11}$ The society had been officially established in New York City on November 17, 1875, when sixteen spiritual seekers came together to attempt to probe explore and synthesize new and old occult traditions in a systematic way (Santucci 231). Blavatsky's leadership and thought were crucial to the early movement; a Russian aristocrat and former spiritualist medium, her two magnum opuses Isis Unveiled (1877) and The Secret Doctrine (1888) formed the core of Theosophy's first-wave teaching. Allegedly written under the inspiration of a secret group of spiritually elevated teachers, known as the Mahatmas or Masters (Sinnett 1883 9), Blavatsky's works describe a spiritually monadic

11 For more on the trajectory and sources for Theosophical reincarnationism, see Chajes 2019. 
universe in which all human souls gradually cycle through a chain of incarnations on earth and other planets before ultimately re-uniting with the Divine. To expedite their progress, individuals could purify themselves through study and initiation in what Blavatsky called the "ancient wisdom tradition" (Chajes Intro 2), a spiritual path preserved and newly revealed within contemporary Theosophy, but by no means originated by it. Those who worked hard to improve their own spiritual lot and to minimize the sufferings of others could accrue good karma for use in subsequent incarnations; those who did not started their next lives in karmic deficit. No sin was so great, however, that it could not ultimately be expiated through trial and penitence. Between lives, individuals were said to rest in the "rosy sleep" of the state known as Devachan for a period of approximately fifteen hundred years (Sinnett 1883 85), restoring themselves before going on the reap the rewards or penalties of their previous actions in a new body.

This cosmological system, developed gradually by Blavatsky over the course of a decade, received its most accessible and popular exposition in late Victorian Britain within two key non-fictional works by Theosophist and newspaper editor Alfred Percy Sinnett (1840-1921): The Occult World (1881) and Esoteric Buddhism (1883). The first documents Blavatsky's, and then Sinnett's own, contact with the Masters; the second focuses on the teachings gained therein. Along with Blavatsky's Isis Unveiled and The Secret Doctrine, the books constitute the most influential and widely circulated texts produced within Theosophy's first wave.

As this brief synopsis suggest, Theosophy's reincarnative schema was driven by the same dissatisfaction with, and moral objection to, punitive accounts of the afterlife simultaneously evident within contemporary Christian denominations. Geoffrey Rowell has shown how theologians came increasingly to challenge the doctrine of damnation over the 
course of the nineteenth century, their critiques impelled by a sense that eternal punishment, even for the most prolific of sinners, was neither "morally defensible" nor "consistent with contemporary ideas of progress and humanitarianism" (152). For A.P. Sinnett, such a fate represented as much a failure of mathematical proportion as it did of moral compassion. "[T]here is a manifest irrationality," he writes in Esoteric Buddhism, in the commonplace notion that man's existence is divided into a material beginning, lasting sixty or seventy years, and a spiritual remainder lasting for ever. The irrationality amounts to absurdity when it is alleged that the acts of the sixty or seventy years-the blundering, helpless acts of ignorant human life-are permitted by the perfect justice of an all-wise Providence to infinite duration. (30) Theosophy, with its clear system of karmic cause and effect, its set pattern of incarnations through a specified planetary chain, promised to provide eschatological order where previously there had reigned only chaos and inequity.

This sense of order and justice also worked to render reincarnation more suitable for fictional exploitation than it had ever, at least in the West, been before. Prior to the advent of Theosophy, the substantially more vague and evasive ideas about metempsychosis present in the Western philosophical tradition via Plato and Plotinus had struggled, not only to take hold, but to make sense in the Victorian literary imagination. ${ }^{12}$ This failure is perhaps nowhere more apparent than in Mortimer Collins's Transmigration (1874), a tripledecker novel published one year prior to the foundation of the Theosophical Society and loosely aligned, via its fleeting allusions to Wordsworth and Pythagoras, with Classical and Romantic concepts of pre-existence and rebirth. Mortimer Collins (1827-1876) is

\footnotetext{
12 For more on these important strains of classical metempsychotic thought and their influence on Theosophy, see Chapter 5 of Chajes' Recycled Lives (2019).
} 
remembered today — when indeed he is at all-as a minor Victorian poet and a Tory journalist who briefly co-edited the London Globe and contributed to Punch and the British Quarterly, among other journals (Mullin). Although there is no evidence that he was ever an occult initiate himself, he is linked to the networks of Victorian esotericism through his status as father of Mabel Collins (1851-1927), the leading first-wave Theosophist who coedited Lucifer with Blavatsky from 1887-1889 and wrote some of the movement's most important early devotional works and trance novels, including Idyll of the White Lotus (1884), Light on the Path (1885), and The Blossom and the Fruit (1888). Mortimer may indeed have been one among many influences on his daughter's spiritual seekership, given the personal and highly eccentric interest in metempsychosis and extreme life extension he pursued both in Transmigration and his anonymously-published The Secret of Long Life (1871).

Across its three volumes, Transmigration tells the story of its protagonist Edward Ellesmere's three consecutive incarnations: the first, in late eighteenth-century Northamptonshire; the second, on the planet Mars, and the third (and perhaps final) in the London suburbs of the book's mid-Victorian publication period. The work seems to have been intended as a serious Utopian romance with a spiritually didactic mission, one which Collins anticipated would elicit comparison to some fairly heavyweight literary forbears. His introduction thus announces that, lest he be suspected of imitation, he has never read Samuel Butler's (1835-1902) Erewhon (1872), and only encountered Edward Bulwer Lytton's (1803-1873)The Coming Race (1871) after his own book had went to press, a protestation that seems driven as much by a desire to position himself within this distinguished literary company as it is by any serious fear that he will be accused of plagiarism. Collins's prose style was, after all, nothing if not distinctive. He concludes with novel with the hope that his 
readers might be inspired to adopt Ellesmere's now-proven faith in reincarnation. "What I have other may do," the character surmises. "I know the soul to be immortal: the unfortunate people who only hope that it is immortal may get proof if they go the right way to work." (III: 290-21). It is difficult, nonetheless, to imagine how any reader might have emerged from Transmigration with a coherent spiritual position of any sort. The novel is a bizarre, often grotesque, and sometimes indecent cosmological picaresque which fluctuates wildly in tone and fails to make sense of reincarnation as anything other than a device through which to prompt its hero's further travels, meals, and seductions.

Transmigration is an attack on stasis of all kinds: of location, of body, and of genre. Its first volume reads like a nostalgic neo-Pickwickian elegy for the lost glories of the English countryside, tracing Ellesmere's first life as a son of the English gentry who studies at Eton, enlists in the Army, runs up debts, and then retires to the countryside to immerse himself in studious isolation after accidentally killing the brother of his beloved fiancée Lucy Lovelace in a spurious duel. With Lucy now (seemingly) forever lost to him, he spends his remaining thirty years in the village of Five Tree Hill, perusing the esoteric library of his deceased landlord Dr Romayne, and generally avoiding all human company except for an unlikely, and sometimes unnervingly intimate, friendship with Mavis Lee, the child of a neighbour. A chance late life meeting brings him back into contact with the now widowed Lucy, and, while they do not resume their courtship, she nurses him as he dies. Volume 2 opens with a vertiginous mode shift; no longer on earth, Ellesmere now finds himself disembodied and floating in a translucent Hall of Spirits deep in space, where he is offered a choice of planet on which to spend his next incarnation. Picking Mars simply for its proximity, he finds himself in a territory which resembles eighteenth-century rural England and classical Greece in equal parts. He wanders through the planet at random, comporting 
with mythological creatures, famous literary characters and lascivious Greek goddesses, and drinking water laced with the deeply intoxicating Martian element of Pyrogen. This plot shares none of the deep moral earnestness of the spiritualist afterlife fictions- Hudson Tuttle's (1836-1910) Scenes in the Spirit Life (1855), for example, or Elizabeth Stuart Phelps'(1844-1911) better-known The Gates Ajar (1868) - by which it seems clearly inspired; it flaunts Collins's oeuvre-wide fixation on food and gustation as Ellesmere plies himself with food and drink in preparation for trysts with the prophetess Cassandra and the beautiful child-woman Alouette, daughter of a Martian King. ${ }^{13}$ Ultimately tired with this constant satiation, Ellesmere returns to earth again in the new body of Reginald Marchmont, son of his former underage love object Mavis Lee. As in his last earth incarnation, he is again heir to a considerable fortune which he puts to good use as he grows to manhood and ultimately wins the hand of Grace Smith, granddaughter of his erstwhile fiancée Lucy Lovelace. The novel ends with their wedding, after which he is able to tell his Grace about the previous lives he has been uniquely permitted to remember because he was in his (presumably?) first incarnation a believer in metempsychosis.

Transmigration appalled critics, and it is not difficult to see why. The novel is so frantically thick with startling, disconnected incidents as to become, perhaps counterintuitively, profoundly boring. "Mr Collins is in great danger of being given up to mere eccentricities," observes the British Quarterly Review. "There is no sequence in $\mathrm{Mr}$ Collins's idea of transmigration; neither duty nor agency is involved in it. It is a mere fancy

\footnotetext{
13 See the review "Transmigration" which appeared in the Saturday Review on February 28 1874, which damningly charges "Every one who has read one of his stories had read them all [ . . .] He takes half-a-dozen heroes or so with vast appetites, and half-a-dozen heroines with appetites, if not quite so vast, and somewhat more dainty, yet sharp enough. In almost every chapter he gives an account of what was eaten, and like a preacher who has chosen a very long text and constantly repeats it in every division of his sermon, easily manages to cover a good deal of ground" (279).
} 
dependent on the fates, not upon ourselves" (574). Indeed, the novel exemplifies in its chaotic wandering style the very problem which the protagonist laments in the Martian segment. "Here I was, free to wander whithersoever I chose, pleasantly surrounded by strange fantasies, free from any kind of care," he remarks. "[Y]et there came on me at intervals a sort of homesickness, a longing for that native sphere where man is born to trouble as the sparks fly upward" (II 260). Ultimately, he pronounces "Man is born to trouble $[\ldots]$ If he is set wholly free from care and annoyance, he loses the strength of his fibre, the fighting power that belongs to him. A tranquil race may dwell on Mars happily enough; it is no place for the beings who commence existence by rebellion and murder" (II 262). This allusion to the foundational episodes of Genesis, namely Eve's temptation and Cain's fratricide, provides a sharp and uncomplimentary contrast to Collins's own whimsical cosmology. While these scriptural incidents set off a fatal, and narratable, chain of cause and effect which Christ, and humanity through Christ, would seek to redress, there is no such similar causational logic in Transmigration. A murderer in his first life, Ellesmere is rewarded with sex and drugs in his second; his third seems near identical to his first. Reincarnation proves here neither progressive, punitive, nor even didactic; after all, the infant Marchmont has to actively conceal the knowledge he acquired in previous lives lest it frighten his loved ones. Arbitrary and aimless, it works to extend human existence without giving it the structure requisite for suspenseful literary plotting and soteriological judgement alike. For reincarnation to work as a fictional device, it would need a much more coherent and personalized structure of cause and effect, a moral impetus that would give meaning to the successive lives delegated to characters. From 1880 onwards, the requirement would be fulfilled increasingly through the principle of karma newly popularized by Theosophy. 
Karma lies at the heart, and forms the title, of leading British Theosophist A.P. Sinnett's 1885 debut novel. A stilted talking-shop of a book, Karma dramatically showcases the representational and ethical dilemma which reincarnation posed for Theosophical fiction writers in the movement's early years. Like many of his co-believers, Sinnett recognized the strong appeal of reincarnation to the late Victorian public, offering, instead of finality and judgment, the potential for both literary sequels and serial lives. This interest would reach a zenith with the publication of H. Rider Haggard's (1856-1925) bestselling She: A History of Adventure (1887); ${ }^{14}$ British Theosophists subsequently capitalized on this success through the regular publication of reincarnation-focused articles and stories in their periodical outlets. ${ }^{15}$ But this diffusion also brought risk; would popularization fuel more garish and spiritually-debased fantasias such as Collins's, or deflect seekers from the true path by fostering the kind of narcissistic obsession with their own past exploits associated with what Olav Hammer terms a "client-centred" (481) approach to reincarnation? How were Theosophists to emplot reincarnation in a way that would simultaneously exploit and withhold its imaginative potential? Sinnett addresses this quandary head on in Karma, without managing to solve it.

The novel appeared at a time when Sinnett, newly elected as President of the TS London Lodge, was widely recognized as Theosophy's leading mouthpiece in Britain. As such, critics recognized in it an earnestness of belief and didactic ambition that they might otherwise have side-lined. The Graphic thus distinguished Karma from Edward Bulwer

\footnotetext{
$14 \quad$ As Roger Luckhurst notes, She "sold twenty-five thousand copies in a matter of weeks and became a global phenomenon" (163), providing Haggard with enough money to undertake a long-anticipated trip to Egypt.

${ }_{15} \quad$ In Lucifer alone, we find the serialized version of Mabel Collins's The Blossom and the Fruit, running from September 1887 to August 1888, alongside reincarnation-focused articles such as W. Kingsland's "Some Thoughts on Karma and Reincarnation" (1888) and W. Ashton Ellis's " "An Infant Genius" (1887).
} 
Lytton's hugely influential occult novel Zanoni (1842) on the basis of its greater "sincerity" and "connection with a distinction and definite theory," noting that "the importance of fiction, as a means of extending the reach of philosophy is recognized by Mr A.P. Sinnett" ("New Novels" 21-2); the Saturday Review described it as "eminently didactic in aim" ("Four Novels" 392), and William Wallace in the Academy deemed this pedagogical purpose so significant as to exempt the novel from literary criticism: "in truth, Karma is not a book to be criticized, but to be believed or disbelieved in" (Wallace 344). Clearly uneasy with fictional form, Sinnett's preferred mode of instruction is definitely to tell rather than show, interpolating the readers as students in various scenes of of occult training. The book is set largely in a remote German castle in which the mysterious occult adept Baron Von Mondstern has assembled a group of leading British intellectuals and opinion makers, figures who, he is convinced, will best be able to convince the public of the truth of occultism once they have seen it demonstrated for themselves. The company spends their days in discussion and practical demonstration of psychical phenomena; the Baron, for example, uses occult force to ring a glass and fell a tree without touching either, while the medium Mrs Lakesby provides psychic surgeries into some of the guests' past lives.

Abandoning this show of wonders part way through, the novel diverges into New Woman territory as it reveals how the respective romantic rejection and sexual transgression of two of the Professor's pupils-Miriam Seaford, the fiancée of journalist Claude Annerly, abandons her partner for the already married Professor Massilton- is a product of the karma they accrued during previous lives in ancient Rome. While the scandal tarnishes the group's reputation, this damage is offset by the achievement of the plot's larger spiritual goal: namely the acceptance, on behalf of the characters, of the reality and morality of karma. 
This acceptance, however, has had to be carefully managed, without too much recourse to titillating demonstration. Mrs Lakesby's scrying sessions into ancient Rome take up only a fraction of a plot which is generally much more comfortable with indirect intellectual exposition. The Baron lectures at great, and to many reviewers, tedious, length about the primacy of reincarnation to human existence, calling it the "only possible solution" to "a great many mysteries of life" (I 172) and insisting that it "must eventually be recognized [ ...] as the crown and complement of evolution already recognized in phyisiology" (I 175). Nonetheless, he hesitates when it comes to probing the records of the group's past lives accessible on the astral plane, warning that "the less interest you take in the theatrical or sensational aspects of occult powers the better" and suggesting they would do better to model their conduct on those singers who learn more by staying at home to practice scales than by going to the opera (I 285). Mondstern's analogy here is telling, combining a focus on individual development with a deep suspicion of performance embodied by the space of the opera house. Rather than spectate or perform, esoteric seekers are bid to practice for no other audience than themselves. This advice nonetheless rings hypocritically hollow in a fictional milieu in which Mondstern's seekers are subjected to constant lecture, and rarely ever shown engaging in personal, practical experiment. Mrs Lakesby is only permitted to scry briefly into the astral plane for the purpose of "discerning the way in which Karma operates" (II 111); "except for this purpose," cautions the Baron, "I am not sure if knowledge about one's previous incarnations could have any other effect than that of feeding personal vanity, and so doing one the worst possible service" (II 106). Willy Blane, one of the group's most advanced students, demonstrates his superior spiritual selflessness by eschewing any interest in his own past incarnations, declaring "I have no personal curiosity about myself-a most uninteresting topic" (II 110). If self-renunciation 
was to be the true goal of esoteric seekership—as for Sinnett it most certainly was-it could not be achieved through extended and lurid recapitulation of our former lives in other times and on other planets. Ultimately, this line of thinking leads Karma to write itself into a corner, unable to exploit the sensational potential of the very principle on which its readerly appeal is premised. In using Theosophy to solve the problem posed by Collins's Transmigration — how to give moral weight and meaning to reincarnation- Sinnett succeeds only in creating a new difficulty: in fictionalizing reincarnation at all, one risked subverting the project of self-abnegation towards which the process was in his estimation geared.

For the less esoterically-affiliated writers of reincarnationist romance who followed in Sinnett's wake, this dilemma simply did not exist; they had no need to curtail their representational scope in line with Theosophical doctrine. Chief among these was queen of the bestsellers Marie Corelli, whose debut occult novel A Romance of Two Worlds (1886) appeared one year after Sinnett's Karma and dramatically outsold it. For Corelli as for fellow romancer $\mathrm{H}$. Rider Haggard, reincarnation would become a fictional dominant motif, featuring as keynote in novels such as Ardath (1889), The Sorrows of Satan (1895), The Life Everlasting (1911), and, most prominently, Ziska (1897). The latter demonstrates the propensity for sustained and eccentric theological exegesis which separates Corelli's reincarnationist plotting from the more action-based narratives of Haggard. Ziska tells the story of the ancient Egyptian dancing girl Ziska-Charmazel who tracks down and enacts revenge on decadent French painter Armand Gervase, the nineteenth-century incarnation of the warrior Araxes who seduced and then killed her in the days of Amenhotep. Whether Ziska is herself a reincarnation of her former avatar, or simply a materialized version of her vengeful soul, is never made exactly clear; the plot's presiding occultist Dr Maxwell Dean 
describes her as a "scientific ghost" whose "outwards appearance of a most beautiful and seductive human body" conceals "the soul of the fiend" (123). Despite this demonic framing, it becomes clear by the end of the novel that Ziska is no stereotypically malevolent femme fatale; on the contrary, she is a wronged woman and a devoted Christian, albeit a decidedly heterodox one ${ }^{16}$ whose ultimate murder of Gervase in a hidden chamber of the Great Pyramid of Giza works to free him from an incessant cycle of punitive incarnations. As Ziska explains to Dean prior to this sensational finale, "those who have never taken the sacred name of Christ to their hearts [. . . ] are left as it were in the vortex of uncertainties, tossed to and fro among many whirling and mighty forces [ . . .]Till they learn and accept the truth, [ . . .] they are the prey of wicked spirits who tempt and lead them on to divers miseries" (69). Gervase and Ziska are liberated alike by this dramatic disbursement of karmic debt, one that Corelli takes as much pains to describe as she does its instigating act of sexual betrayal in Pharaonic Egypt. One of the most popular novels of its publication year, ${ }^{17}$ Ziska promotes a brand of reincarnation which successfully fuses the exoticism, sensuality and incident of Collins's Transmigration with the causational logic and morally redemptive mandate of Sinnett.

In the decades which followed, reincarnation would continue to be retooled in popular and avant garde literature alike, featuring in works as diverse as James Joyce's Ulysses (1922), Joan Grant's Winged Pharaoh (1937), and Dennis Wheatley's The Ka of Gifford Hillary (1956). The present ubiquity of reincarnation as a cultural concept, if not belief-although, as Olav Hammer points out, some polls have suggested its uptake by

\footnotetext{
16 She practices a version of Hermetic Christianity which combines faith in Christ's salvific power with a belief in reincarnation.

17 The Bookman reported that 40,000 advance copies of Ziska had been ordered in the month before its publication; after its issue, it featured on the Academy's list of 'most bought titles" for most of the spring "Monthly Report of the Wholesale Book Trade" and "The Book Market."
} 
approximately $20 \%$ of the American population (455) - owes much to these fictional treatments, even though a substantial history of literary reincarnationism has yet to be written. First emerging in the late nineteenth century, the reincarnation novel captures the dynamic religious transformations underway in the era which gave it birth; reflecting an ongoing attraction to independent spiritual inquiry and eclecticism of belief fostered by secularization, it also compels us to rethink the primacy and utility of the faith and doubt paradigm to the Victorian religious landscape. Reincarnationism, like Victorian esoteric movements more broadly, allowed individuals to be believing doubters, sceptical of the old hellfire sermons but confident that death was not the end, and able to experience the loss of traditional faith as the source of renewed spiritual optimism. Reworking the Latin credo of Dum spiro spero, esoteric reincarnationists found hope not (just) in life, but perhaps most profoundly in a death which was only ever temporary, in a cosmos which continually extended the possibility of one more shot at karmic restitution, pursued in, rather than out, of the flesh. "A new birth," as Christian esotericist Marie Sinclair, the Countess of Caithness (1830-1895), writes in Old Truths in a New Light, "provides a new and pliant brain as a clean page on which to record new impressions of a new period, a new age, and of new surroundings" (417). Her metaphor beautifully captures the literary alignments, stakes, and consequences of esoteric and new religious movements at the fin de siecle as their beliefs fuelled fiction pages and faith alike. 


\section{Key Critical Works}

Joy Dixon. Divine Feminine: Feminism and Theosophy in England.

Julie Chajes. Recycled Lives: A History of Reincarnation in Blavatsky's Theosophy.

Joscelyn Godwin. The Theosophical Enlightenment.

Nicholas Goodrick-Clarke. The Western Esoteric Traditions: A Historical Introduction.

Olav Hammer. Claiming Knowledge: Strategies of Epistemology from Theosophy to the New Age.

Wouter Hanegraaff. Esotericism and the Academy: Rejected Knowledge in Western Culture. Janet Oppenheim. The Other World: Spiritualism and Psychical Research in England, 18501914 .

Alex Owen. The Darkened Room: Women, Power, and Spiritualism in Late Victorian England. The Place of Enchantment: British Occultism and the Culture of the Modern. 


\section{Works Cited}

Adversa. "Our Christian XIXth Century Ethics." Lucifer, 2.12, August 1888, pp. 482-5. Arnold, Matthew. "Dover Beach." The Norton Anthology of English Literature. Edited by Stephen Greenblatt and M.H. Abrams. W.W. Norton and Co., 2006. Volume E The Victorian Age, pp. 1368-9.

Bergunder, Michael. "What is Esotericism? Cultural Studies Approaches and the Problems of Definition in Religious Studies." Method and Theory in the Study of Religions. 22.1, 2010, pp. 9-36.

Blavatsky, H.P. Isis Unveiled: A Master-Key to the Mysteries of Ancient and Modern Science and

Theology. Volume 1. Theosophical University Press Web Edition.

<https://www.theosociety.org/pasadena/isis/iu1-ooin.htm\#contents>.

Bogdan, Henrik. "Western Esotericism and New Religious Movements." The Oxford Handbook of New Religious Movements: Volume 2. Edited by James R. Lewis and Inga Tøllefson. Oxford UP, 2016, pp. 455-466.

"The Book Market." The Academy. (February 20 1897), p. 238.

Butler, Samuel. Erewhon; or, Over the Range. Trübner, 1872.

Caithness, Countess of [Marie Sinclair]. Old Truths in a New Light, or, An Earnest Endeavour to Reconcile Material Science and Spiritual Science, with Scripture. Chapman and Hall, 1876.

Census of Great Britain 1851: Religious Worship in England and Wales. G. Routledge \& Co., 1854 .

Chajes, Julie. Recycled Lives: A History of Reincarnation in Blavatsky's Theosophy. Oxford UP, 2019 
Chambers, Richard. Vestiges of the Natural History of Creation and Other Evolutionary Writings. 1844. University of Chicago Press, 1994.

Collins, Mabel. The Blossom and the Fruit: A True Story of a Black Magician.

Published by the Authors. 1888.

The Idyll of the White Lotus. Reeves and Turner, 1884.

Light on the Path: A Treatise written for the personal use of those who are ignorant of the Eastern wisdom and who desire to enter within its influence. Reeves and Turner, 1885 .

Collins, Mortimer. Transmigration. 3 Volumes. Hurst and Blackett, 1874.

The Secret of Long Life. 1871.

Corelli, Marie. Ardath: The Story of a Dead Self. Richard Bentley, 1889.

The Life Everlasting: A Reality of Romance. A.L. Burt, 1911.

A Romance of Two Worlds. Richard Bentley, 1886.

The Sorrows of Satan. Methuen \& Co., 1895.

Ziska: The Problem of a Wicked Soul. 1897. Valancourt Books, 2009.

Ellis, W. Ashton. "An Infant Genius." Lucifer. 1.4, December 1887, pp. 296-98.

"Esotericism." Oxford English Dictionary. http://www.oed.com

"Four Novels." Saturday Review of Politics, Literature, Science, and Art, Sept 19 1885, pp. 392-4.

Gilbert, Robert Andrew. The Great Chain of Unreason: The Publication and Distribution of the Literature of Rejected Knowledge in England during the Victorian Era. Diss. University of London, 2009. Web. 31 August 2018.

Godwin, Joscelyn. The Theosophical Enlightenment. SUNY Press, 1994.

Grant, Joan. Winged Pharaoh. Arthur Baker, 1937. 
Haggard, H. Rider. She: A History of Adventure. Longmans, Green, and Co., 1887.

Hammer, Olav and Mikael Rothstein. "Introduction." The Cambridge Companion to New Religious Movements. Edited by Olav Hammer and Mikael Rothstein. Cambridge UP 2012, pp. 1-9.

Hammer, Olav. Claiming Knowledge: Strategies of Epistemology from Theosophy to the New Age. Brill, 2004.

Hanegraaff, Wouter. "Esotericism." Dictionary of Gnosis and Western Esotericism. Edited by Wouter Hanegraaff. Brill, 2006, pp. 336-40.

Esotericism and the Academy: Rejected Knowledge in Western Culture. Cambridge UP, 2012.

"Is Theosophy a Religion?" Lucifer. 3.15, November 1888, pp. 177-87.

Joyce, James. Ulysses. Sylvia Beach, 1922.

King, Joshua. Imagined Spiritual Communities in Britain's Age of Print. Ohio State UP, 2015.

Kingsland, W. "Some Thoughts on Karma and Reincarnation." Lucifer. 2.8, April 1888, pp. $122-26$.

Knight, Mark and Emma Mason. Nineteenth-Century Religion and Literature: An Introduction.

Oxford UP, 2006.

Larsen, Timothy. Crisis of Doubt: Honest Faith in Nineteenth-Century England. Oxford UP, 2006.

Lewis, James R. Legitimating New Religions. Rutgers UP, 2003.

Lewis, James R. and Inga Tøllefson. "Introduction." The Oxford Handbook of New Religious 
Movements: Volume 2. Edited by James R. Lewis and Inga Tøllefson. Oxford UP, 2016, pp. 1-14.

"Lucifer to the Archbishop of Canterbury." Lucifer. 1.4, December 1887, pp. 241-51.

Luckhurst, Roger. The Mummy's Curse: The True History of a Dark Fantasy. Oxford UP, 2012.

Lytton, Edward Bulwer. The Coming Race. William Blackwood and Sons, 1871.

Melnyk, Julie. Victorian Religion: Faith and Life in Britain. Praeger, 2008.

"Monthly Report of the Wholesale Book Trade." The Bookman, February 1897, pp. 135-6.

Mullin, Katherine. "Collins, (Edward James) Mortimer (1827-1876), novelist and journalist." Oxford Dictionary of National Biography. http://www.oxforddnb.com.

"New Novels." Graphic, 30 May 1885, pp. 21-22. Web.

Oppenheim, Janet. The Other World: Spiritualism and Psychical Research in England, 18501914. Cambridge UP, 1985.

"Opinions of the Press." Appendix to Karma. By A.P. Sinnett. Chapman and Hall, 1885 .

Owen, Alex. The Darkened Room: Women, Power, and Spiritualism in Late Victorian England. University of Chicago Press, 1989.

The Place of Enchantment: British Occultism and the Culture of the Modern. University of Chicago Press, 2004.

Phelps, Elizabeth Stuart. The Gates Ajar. Houghton, Osgood, 1868.

"Recent Novels." The Times, 31 July 1885, p. 13.

Rowell, Geoffrey. Hell and the Victorians: A Study of the Nineteenth-Century Theological 
Controversies Concerning Eternal Punishment and the Future Life. Clarendon Press, 1974 .

Ruskin to Henry Acland, May 24 1851. The Complete Works of Ruskin. Edited by E.T. Cooke and Alexander Wedderburn. Allen, 1903-1912. Volume 36: p. 115.

Santucci, James. "The Theosophical Society." Dictionary of Gnosis and Western Esotericism. Edited by Wouter Hanegraaff. Brill, 2006, pp. 1114-1123.

"Theosophy." The Cambridge Companion to New Religious Movements. Cambridge UP, 2012; pp. 231-46.

Sinnett, A. P. Esoteric Buddhism. Trübner and Co., 1883.

Karma. 2 Volumes. Chapman and Hall, 1885.

The Occult World. Trübner and Co., 1881.

Sommers, Susan Mitchell. The Siblys of London: A Family on the Esoteric Fringes of Georgian England. Oxford UP, 2018.

Stuckrad, Kocku Von. "Western Esotericism: Towards an Integrative Model of Interpretation." Religion. 35.2, 2005, pp. 78-97.

"Sunday Devotion to Pleasure." Lucifer. 2.7, March 1888, pp. 1-5.

"Transmigration." British Quarterly Review. 118, April 1874, pp. 574-5.

"Transmigration." Saturday Review of Politics, Literature, Science, and Art, 28 February 1874,

pp. $279-80$.

Tuttle, Hudson. Scenes in the Spirit World; or, Life in the Spheres. Partridge and Britten, 1855 .

Wallace, William. "New Novels." The Academy, 16 May 1885, p. 344.

Wolff, Robert Lee. Gains and Losses: Novels of Faith and Doubt in Victorian England. John 
Murray, 1977.

Zander, Helmut. "Reincarnation II: Renaissance-Present." Dictionary of Gnosis and Western Esotericism. Edited by Wouter Hanegraaff. Brill, 2006, pp. 983-87. 